\title{
Evaluation and Selection of Date Palm Varieties from Seedling Progeny in Saudi Arabia
}

\author{
Ibrahim Abdoulhadi Al-Abdoulhadi \\ Date Palm Research Centre, P. O. Box 43, Al-Hassa 31982, Kingdom of Saudi Arabia
}

\begin{abstract}
A survey was conducted in 2011 in the major date growing regions of Saudi Arabia to identify and evaluate date palms with fruit characteristics preferred by the producers and consumers. The regions in the Kingdom surveyed for this purpose were Al-Zulfi, Al-Hassa, Najran, Al-Madinah Al-Munawarah and Al-Qassim. Seventy palms from seedlings were initially identified for the study based on the following fruit characteristics, i.e., fruit length, breadth, weight, color, taste, texture, sugar content, external appearance and also the market value. Subsequently, 12 palms (Al-Afiah, Duhiba, Adbah, Aliah, Shamshula, Masifat Al-Asedy, Suwaid, Batlyah, Al-Nassar, Hussan, Sukariyat Al-Zulfi and Al-Hamat) mainly from the Zulfi and Riyadh regions were found to meet the required standards with potential for commercial date farming. Among these, fruits of Adbah had the highest total sugars of $72.9 \%$ followed by Duhiba with a total sugar content of $71.9 \%$. Fruit length was maximum $(49.1 \mathrm{~mm})$ in the variety Aliah, while the fruits of the variety Hussan recorded the maximum weight of $19.5 \mathrm{~g}$. Furthermore, it is pertinent to mention that fruit size of the 12 selected cultivars was generally large and comparable to Majdool, a well-known date palm cultivar of North Africa. The fruits of the selected cultivars were also tasty and can be stored separately.
\end{abstract}

Key words: Fruit characteristics, Phoenix dactylifera, seedling date palm, Saudi Arabia.

\section{Introduction}

Date palm Phoenix dactylifera L. is an important fruit crop in the palm family (Arecaceae) cultivated in the arid regions of the world including the Arabian Peninsula, Middle East and North Africa since pre-historic times where it is closely associated with the life and culture of the people. It is estimated that there are 100 million date palms cultivated in an estimated 1 million ha of which $60 \%$ exist in the Arab world. Ten countries in the Middle East and North Africa account for $90 \%$ of the world's production. The geographical dispersal of dates by seeds is the oldest and most prevalent; the progeny commonly are designated as seedling dates [1]. In the Americas, the first date palm plantings were from seeds carried from Spain and North Africa [2]. The date palm fruit is a drupe and exhibits a high diversity in texture, shape, color and chemical composition depending on the

Corresponding author: Ibrahim Abdoulhadi Al-Abdoulhadi, M.Sc., research field: date palm production. E-mail: hadiibrahim@hotmail.com. genotype, environment, season and cultural practices. The fruit typically characterizes the variety [3]. The global date production has increased from just 1.8 million tons in 1962 to 7.5 million tons in 2013 [4]. The Kingdom of Saudi Arabia produces about 1.3 million tons of dates annually, accounting for $17 \%$ of the global date production [4] and ranking third in the world in terms of production. Besides being a very good source of food, dates are reported to have several medicinal qualities, i.e., antibacterial, antifungal, antitumor, antiulcer and immuno-modulatory properties. Recently, the antioxidant activity of some cultivars was investigated and attributed to phenolic compounds [3, 5-7].

It has been estimated that there are 3,000 cultivars of date palm worldwide [8], but it is widely suspected that many of the names represent synonyms [2]. Saudi Arabia has a rich diversity of about 400 date cultivars, of which 10 varieties are popular, have a high consumer preference in different regions of the Kingdom [9] and are propagated by offshoots as 
commonly practiced by the farmers and also through tissue culture. Besides the known date palm cultivars in the Kingdom, there is a wide range of elite germplasm of date palm originating from seedlings, many of which are propagated and traded among the date palm farmers in different regions of Saudi Arabia. Farmers usually rely on the physical traits of the fruits that have a high degree of consumer preference to select better seedling progeny of date palm. Over the years, the present well known cultivars of date palm in Saudi Arabia and also in other date growing countries have evolved from seedlings selected by date palm farmers for good fruit qualities (mostly bigger fruit size).

The objective of this study was to identify, evaluate and conserve precious resource of elite date palms originating from seedlings in the five major date palm growing regions of Saudi Arabia. Protocols adopted to carry out this study are described below.

\section{Materials and Methods}

The survey was conducted in five major date growing regions of Saudi Arabia during 2011. The regions in the Kingdom surveyed for this purpose were Al-Zulfi, Al-Hassa, Najran, Al-Madinah Al-Munawarah and Al-Qassim. The palms studied were 45-50 years old, were propagated by the farmers through offshoots and have a known mother palm.

Elite seedling progeny was identified based on the following five aspects: (1) popularity in the region and if named after a farmer or his family; (2) high market value; (3) availability of offshoots on mother palm to facilitate propagation and demand for offshoots among farmers; (4) good fruit characteristics with respect to size, color, texture, number of seeds and amount \& clarity of deebs (date honey); (5) medicinal properties if any.

Data of the potential seedling date palm was collected on the following aspects: (1) local name of the progeny; (2) number of palms in the region; (3) morphological traits of the seedling palm with respect to the trunk and length of frond mid-rib. Length of frond mid-rib with spines were recorded in three replicates and physical characteristics of the fruits pertaining to fruit length, breath and weight were recorded in 50 fruits.

With respect to the 12 elite seedling date palms from Al-Zulfi, total sugar, glucose, fructose and sucrose content were determined as per the protocols recommended by the Association of Official Agricultural Chemists (AOAC) [10]. The location of the mother palm was determined by identifying the GPS coordinates. Data on the characters studied were subjected to ANOVA $(P=0.05)$ utilizing the web based statistical package (WASP 1) available at www.icargoa.res.in. Results are presented and discussed below.

\section{Results}

Results presented in Tables 1-6 reveal that the sample mean for all the characteristics of the seedling date palms studied was significant (ANOVA, $P=$ 0.05 ), indicating wide variability among the seedling progeny population for every trait studied. Fruit weight for the varieties from Al-Zulfi and Al-Qassim were not significantly different. As regards the Al-Zulfi region of Saudi Arabia where the practice of growing elite seedling date palms is popular among the farmers, 70 palms from seedlings were initially located for the study. Subsequently, 25 potential seedling palms were identified from the Al-Zulfi region, of which 12 palms (Al-Afiah, Duhiba, Adbh, Aliah, Shamshula, Masifat Al-Asedy, Suwaid, Batlyah, Al-Nassar, Hussan, Sukariyat Al-Zulfi and Al-Hamat) were found to meet the required standards with potential for commercial date farming. As regards to the vegetative traits studied, the varieties Al-Afiah and Al-Nasser recorded the maximum stem girth of $2.3 \mathrm{~m}$ with frond mid-rib length varying from $4.0 \mathrm{~m}$ to $3.1 \mathrm{~m}$ among the 12 cultivars, while the maximum length of the frond mid-rib $(2.1 \mathrm{~m})$ was registered in the cultivar Hussan. 
Table 1 Morphological characteristics of seedling date palm cultivars from Al-Zulfi region of Saudi Arabia.

\begin{tabular}{|c|c|c|c|c|c|c|}
\hline Sr. No. & Cultivar & $\begin{array}{l}\text { Location: } \\
\text { GPS coordinates }\end{array}$ & Stem girth $(\mathrm{m})$ & Stem length (m) & Frond mid-rib length (m) & $\begin{array}{l}\text { Length of frond mid-rib } \\
\text { with spines }(\mathrm{m})\end{array}$ \\
\hline 1 & Al-Afiah & $\begin{array}{l}44^{\circ} 50^{\prime} 20^{\prime \prime} \mathrm{N} \\
26^{\circ} 15^{\prime} 56^{\prime \prime} \mathrm{E}\end{array}$ & $2.3^{\mathrm{ab}}$ & $2.1^{\mathrm{ij}}$ & $3.2^{\mathrm{e}}$ & $1.4^{\mathrm{g}}$ \\
\hline 2 & Duhiba & $\begin{array}{l}44^{\circ} 50^{\prime} 25^{\prime \prime} \mathrm{N} \\
26^{\circ} 16^{\prime} 04^{\prime \prime} \mathrm{E}\end{array}$ & $2.1^{\mathrm{cd}}$ & $1.9^{\mathrm{j}}$ & $3.2^{\mathrm{e}}$ & $1.6^{\mathrm{de}}$ \\
\hline 3 & Adbah & $\begin{array}{l}44^{\circ} 50^{\prime} 24^{\prime \prime} \mathrm{N} \\
26^{\circ} 16^{\prime} 04^{\prime \prime} \mathrm{E}\end{array}$ & $2.2^{\mathrm{bc}}$ & $1.9^{\mathrm{j}}$ & $3.2^{\mathrm{e}}$ & $1.6^{\mathrm{de}}$ \\
\hline 4 & Aliah & $\begin{array}{l}44^{\circ} 50^{\prime} 20^{\prime \prime} \mathrm{N} \\
26^{\circ} 16^{\prime} 05^{\prime \prime} \mathrm{E}\end{array}$ & $2.1^{\mathrm{cd}}$ & $4.0^{\mathrm{f}}$ & $3.1^{\mathrm{ef}}$ & $1.7^{\mathrm{c}}$ \\
\hline 5 & Shamshula & $\begin{array}{l}44^{\circ} 50^{\prime} 18^{\prime \prime} \mathrm{N} \\
26^{\circ} 15^{\prime} 56^{\prime \prime} \mathrm{E}\end{array}$ & $1.7^{\mathrm{g}}$ & $5.7^{\mathrm{d}}$ & $3.8^{\mathrm{bc}}$ & $1.5^{\mathrm{f}}$ \\
\hline 6 & Masifat Al-Asedy & $\begin{array}{l}44^{\circ} 50^{\prime} 10^{\prime \prime} \mathrm{N} \\
26^{\circ} 15^{\prime} 57^{\prime \prime} \mathrm{E}\end{array}$ & $1.9^{\mathrm{ef}}$ & $5.1^{\mathrm{e}}$ & $3.0^{\mathrm{f}}$ & $1.2^{\mathrm{h}}$ \\
\hline 7 & Suwaid & $\begin{array}{l}44^{\circ} 51^{\prime} 40^{\prime \prime} \mathrm{N} \\
26^{\circ} 12^{\prime} 55^{\prime \prime} \mathrm{E}\end{array}$ & $1.8^{\mathrm{fg}}$ & $6.9^{\mathrm{a}}$ & $3.9^{\mathrm{b}}$ & $1.9^{\mathrm{b}}$ \\
\hline 8 & Batlyah & $\begin{array}{l}44^{\circ} 51^{\prime} 42^{\prime \prime} \mathrm{N} \\
26^{\circ} 12^{\prime} 55^{\prime \prime} \mathrm{E}\end{array}$ & $2.0^{\mathrm{de}}$ & $6.4^{\mathrm{b}}$ & $3.8^{\mathrm{bc}}$ & $1.9^{\mathrm{b}}$ \\
\hline 9 & Al-Nassar & $\begin{array}{l}44^{0} 49^{\prime} 01^{\prime \prime} \mathrm{N} \\
26^{\circ} 13^{\prime} 39^{\prime \prime} \mathrm{E}\end{array}$ & $2.3^{\mathrm{ab}}$ & $2.3^{\mathrm{hi}}$ & $3.9^{\mathrm{b}}$ & $1.3^{\mathrm{g}}$ \\
\hline 10 & Hussan & $\begin{array}{l}44^{\circ} 51^{\prime} 42^{\prime \prime} \mathrm{N} \\
26^{\circ} 13^{\prime} 01^{\prime \prime} \mathrm{E}\end{array}$ & $1.9^{\mathrm{ef}}$ & $3.1^{\mathrm{g}}$ & $4.0^{\mathrm{a}}$ & $2.1^{\mathrm{a}}$ \\
\hline 11 & Sukariyat Al-Zulfi & $\begin{array}{l}44^{\circ} 50^{\prime} 19^{\prime \prime} \mathrm{N} \\
26^{\circ} 15^{\prime} 57^{\prime \prime} \mathrm{E}\end{array}$ & $1.8^{\mathrm{g}}$ & $2.5^{\mathrm{h}}$ & $3.7^{\mathrm{d}}$ & $1.6^{\mathrm{de}}$ \\
\hline 12 & Al-Hamad & $\begin{array}{l}44^{\circ} 50^{\prime} 19^{\prime \prime} \mathrm{N} \\
26^{\circ} 15^{\prime} 57^{\prime \prime} \mathrm{E}\end{array}$ & $1.7^{\mathrm{g}}$ & $6.0^{\mathrm{c}}$ & $3.7^{\mathrm{cd}}$ & $1.5^{\mathrm{ef}}$ \\
\hline \multicolumn{3}{|c|}{$\mathrm{CD}(P=0.05)$} & 0.16 & 0.25 & 0.13 & 0.10 \\
\hline
\end{tabular}

${ }^{\mathrm{a}-\mathrm{j}}$ Means within the column followed by the same letters are not significantly different; CD: critical difference.

Table 2 Physical and chemical characteristics of dates from seedling date Palm cultivars of Al-Zulfi region in Saudi Arabia.

\begin{tabular}{|c|c|c|c|c|c|c|c|}
\hline \multirow{2}{*}{ Sr. No. } & \multirow{2}{*}{ Cultivar } & \multicolumn{3}{|c|}{ Physical characteristics of fruit } & \multicolumn{3}{|c|}{ Sugar content $(\%)$} \\
\hline & & Length (mm) & Width (mm) & Weight $(\mathrm{g})$ & Glucose & Fructose & Total sugars \\
\hline 1 & Al-Afiah & $45.1^{\mathrm{d}}$ & $25.6^{\mathrm{c}}$ & $16.5^{\mathrm{c}}$ & $34.2^{\mathrm{f}}$ & $31.5^{\mathrm{c}}$ & $65.9^{f}$ \\
\hline 2 & Duhiba & $33.2^{\mathrm{k}}$ & $24.6^{\mathrm{d}}$ & $13.6^{\mathrm{e}}$ & $39.0^{\mathrm{a}}$ & $33.9^{\mathrm{a}}$ & $71.9^{\mathrm{b}}$ \\
\hline 3 & Adbah & $47.0^{\mathrm{c}}$ & $27.4^{\mathrm{b}}$ & $19.2^{\mathrm{a}}$ & $39.0^{\mathrm{a}}$ & $33.9^{\mathrm{a}}$ & $72.9^{\mathrm{a}}$ \\
\hline 4 & Aliah & $48.7^{\mathrm{b}}$ & $23.6^{\mathrm{ef}}$ & $18.2^{\mathrm{b}}$ & $33.8^{\mathrm{g}}$ & $31.0^{\mathrm{f}}$ & $65.0^{\mathrm{g}}$ \\
\hline 5 & Shamshula & $41.7^{\mathrm{f}}$ & $23.9^{\mathrm{e}}$ & $18.2^{\mathrm{b}}$ & $33.8^{\mathrm{g}}$ & $31.0^{\mathrm{f}}$ & $64.9^{\mathrm{h}}$ \\
\hline 6 & Masifat Al-Asedy & $51.2^{\mathrm{a}}$ & $21.3^{\mathrm{h}}$ & $15.5^{\mathrm{d}}$ & - & - & - \\
\hline 7 & Suwaid & $43.4^{\mathrm{e}}$ & $22.2^{\mathrm{g}}$ & $14.5^{\mathrm{e}}$ & $35.0^{\mathrm{d}}$ & $31.1^{\mathrm{e}}$ & $66.3^{\mathrm{d}}$ \\
\hline 8 & Batlyah & $39.9^{\mathrm{g}}$ & $23.2^{\mathrm{ef}}$ & $13.1^{\mathrm{g}}$ & $32.1^{\mathrm{h}}$ & $28.7^{\mathrm{h}}$ & $60.8^{\mathrm{i}}$ \\
\hline 9 & Al-Nassar & $38.8^{\mathrm{h}}$ & $23.5^{\mathrm{ef}}$ & $10.5^{\mathrm{i}}$ & $37.6^{\mathrm{b}}$ & $32.7^{\mathrm{b}}$ & $68.3^{\mathrm{c}}$ \\
\hline 10 & Hussan & $36.9^{\mathrm{i}}$ & $28.2^{\mathrm{a}}$ & $19.4^{\mathrm{a}}$ & $35.1^{\mathrm{c}}$ & $30.9^{\mathrm{g}}$ & $66.0^{\mathrm{e}}$ \\
\hline 11 & Sukariyat Al-Zulfi & $35.5^{\mathrm{j}}$ & $23.0^{\mathrm{f}}$ & $11.8^{\mathrm{h}}$ & $34.9^{\mathrm{e}}$ & $31.3^{\mathrm{d}}$ & $66.3^{\mathrm{e}}$ \\
\hline 12 & Al-Hamad & $36.4^{\mathrm{ij}}$ & $26.1^{\mathrm{c}}$ & $14.5^{\mathrm{e}}$ & $30.7^{\mathrm{i}}$ & $27.3^{\mathrm{i}}$ & $58.0^{\mathrm{j}}$ \\
\hline \multicolumn{2}{|c|}{$\mathrm{CD}(P=0.05)$} & $0.9^{8}$ & 0.67 & 0.30 & 0.09 & 0.05 & 0.29 \\
\hline
\end{tabular}

${ }^{\mathrm{a}-\mathrm{k}}$ Means within the column followed by the same letters are not significantly different; $\mathrm{CD}$ : critical difference.

The reproductive character of fruit size and weight of the 12 selected cultivars were generally very large (Table 2, Figs. 1 and 2) with good taste and fruits that can be stored separately and comparable to Majdool, a well-known date palm variety of North Africa. As regards fruit quality, the highest sugar content was 
Al-Aflah
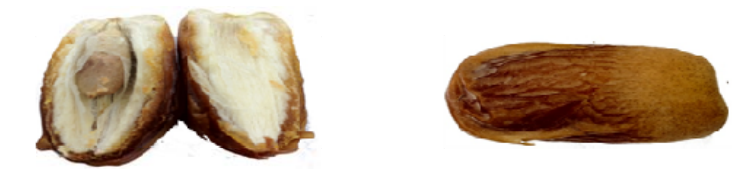

Duhiba
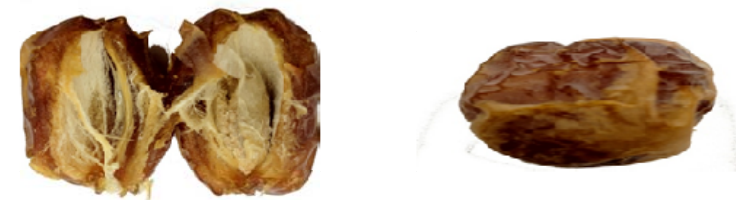

Adbah
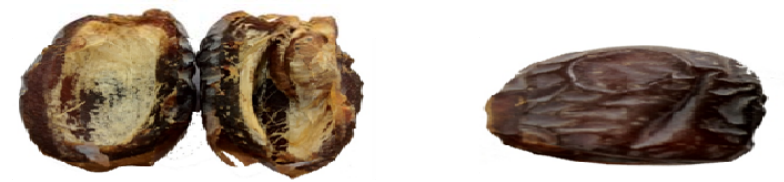

Aliah
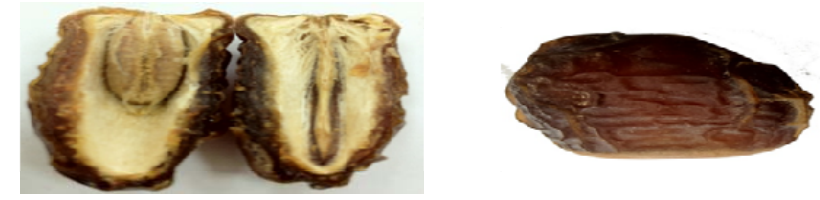

Shamshula
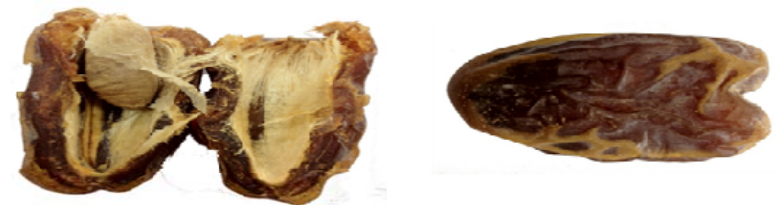

Batlyah
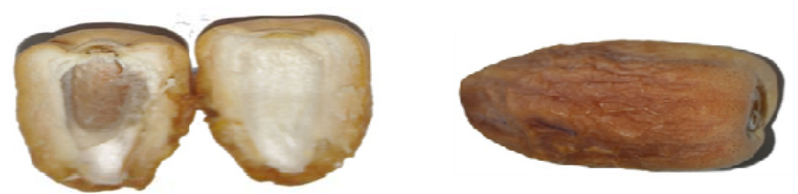

Fig. 1 Fruits of important date palm cultivars from Al-Zulfi region of Saudi Arabia.

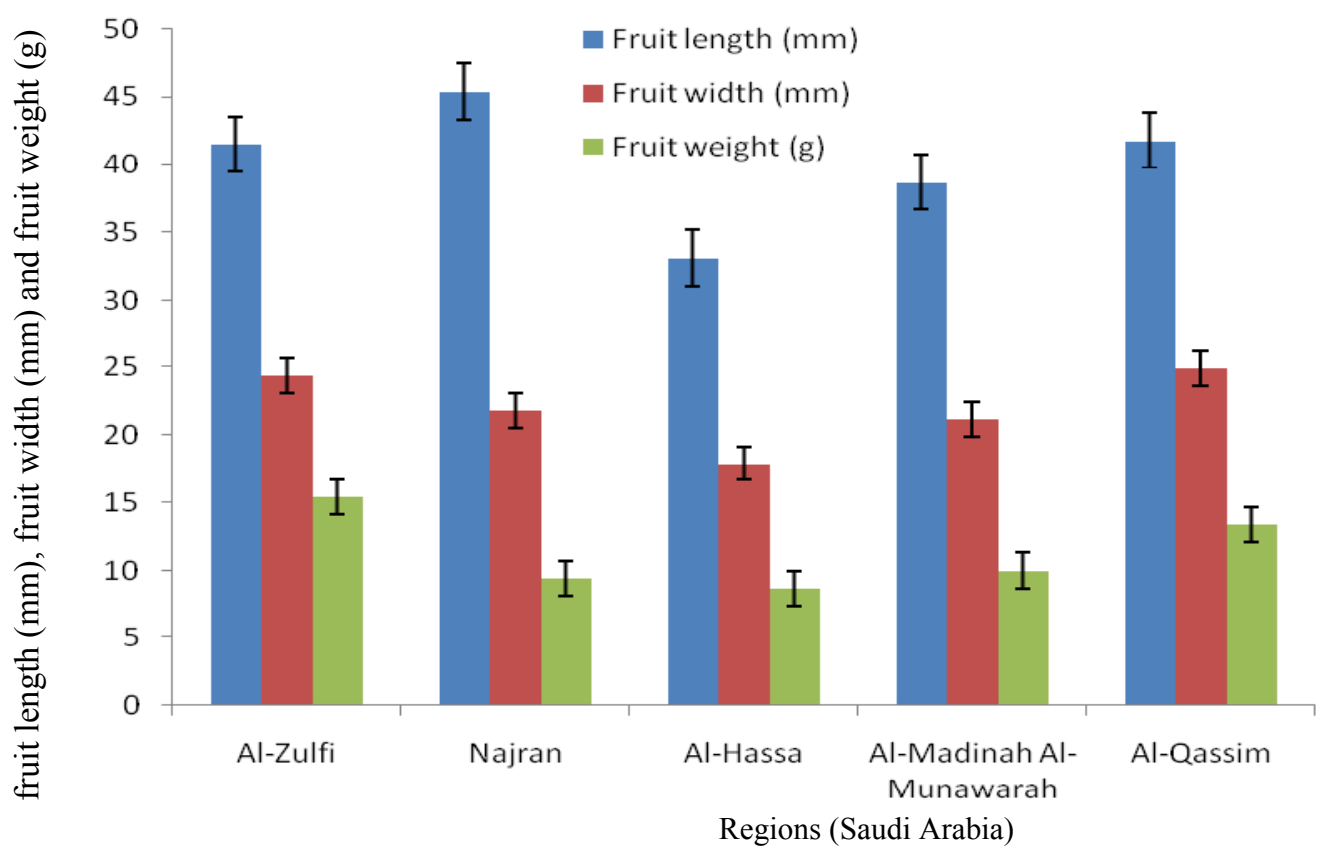

Fig. 2 Physical characteristics of dates from seedling progeny from different regions of Saudi Arabia. 
recorded in the cultivar Adbah. It is pertinent to mention that the fruits of these 12 cultivars had a high content of glucose (34.9\%-39.0\%) and fructose $(28.7 \%-33.9 \%)$ and were devoid of sucrose. The values for sugars indicate the portion of sugar in $100 \mathrm{~g}$ of fruit.

From Najran (Table 3), the cultivar Muwakeel recorded the best fruit length $(46.7 \mathrm{~mm})$ and weight (9.6 g), while the cultivar Beyad recorded the maximum fruit width $(23.2 \mathrm{~mm})$.

Among the nine elite seedling progeny palms selected from Al-Hassa (Table 4), cultivar H-2 registered maximum fruit length $(40.7 \mathrm{~mm})$. As regards fruit width and weight, the best results among the Al-Hassa cultivars were recorded in cultivar number one where the mean fruit width was $23.5 \mathrm{~mm}$ with fruit weight being $15.2 \mathrm{~g}$.

Data in Table 5 reveals that fruits of seedling MM-4 from Al-Madinah Al-Munawarah region had the maximum average length $(45.5 \mathrm{~mm})$ and weight $(12.8$ $\mathrm{g})$, while seedling number one recording the best fruit width $(23.3 \mathrm{~mm})$.

In Al-Qassim region, 22 elite seedlings of date palm were identified during this study (Table 6), from which cultivar number 6427 recorded the maximum fruit length $(47.6 \mathrm{~mm})$, while the cultivars Bedah-1 and Hamdan-1 recorded the highest fruit width and weight of $30.3 \mathrm{~mm}$ and $23.1 \mathrm{~g}$, respectively.

Table 3 Physical characteristics of dates from seedling date palm cultivars of Najran region in Saudi Arabia.

\begin{tabular}{lllll}
\hline Sr. No. & Cultivar & Fruit length $(\mathrm{mm})$ & Fruit width $(\mathrm{mm})$ & Fruit weight $(\mathrm{g})$ \\
\hline 1 & Muwakeel & $46.7^{\mathrm{a}}$ & $20.5^{\mathrm{b}}$ & $9.6^{\mathrm{a}}$ \\
2 & Beyad & $44.1^{\mathrm{b}}$ & $23.2^{\mathrm{a}}$ & $9.1^{\mathrm{b}}$ \\
\hline $\mathrm{CD}(P=0.05)$ & & 0.87 & 0.86 & 0.23 \\
\hline
\end{tabular}

${ }^{\mathrm{a}, \mathrm{b}}$ Means within the column followed by the same letters are not significantly different; $\mathrm{CD}$ : critical difference.

Table 4 Physical characteristics of dates from seedling date palm cultivars of Al-Hassa region in Saudi Arabia.

\begin{tabular}{llll}
\hline Cultivar code & Fruit length $(\mathrm{mm})$ & Fruit width $(\mathrm{mm})$ & Fruit weight $(\mathrm{g})$ \\
\hline H-1 & $39.1^{\mathrm{c}}$ & $23.5^{\mathrm{a}}$ & $15.2^{\mathrm{a}}$ \\
H-2 & $40.7^{\mathrm{a}}$ & $19.0^{\mathrm{c}}$ & $11.8^{\mathrm{b}}$ \\
H-3 & $39.9^{\mathrm{b}}$ & $22.8^{\mathrm{b}}$ & $12.2^{\mathrm{b}}$ \\
H-4 & $31.5^{\mathrm{f}}$ & $17.6^{\mathrm{e}}$ & $7.1^{\mathrm{d}}$ \\
H-5 & $29.3^{\mathrm{g}}$ & $15.6^{\mathrm{g}}$ & $6.2^{\mathrm{e}}$ \\
H-6 & $32.5^{\mathrm{e}}$ & $17.1^{\mathrm{f}}$ & $8.2^{\mathrm{c}}$ \\
H-7 & $24.9^{\mathrm{h}}$ & $11.8^{\mathrm{h}}$ & $3.6^{\mathrm{g}}$ \\
H-8 & $36.8^{\mathrm{d}}$ & $18.5^{\mathrm{d}}$ & $8.4^{\mathrm{c}}$ \\
H-9 & $23.3^{\mathrm{i}}$ & $15.6^{\mathrm{g}}$ & $5.7^{\mathrm{f}}$ \\
\hline CD $(P=0.05)$ & 0.55 & 0.47 & 0.47 \\
\hline
\end{tabular}

${ }^{\mathrm{a}-\mathrm{i}}$ Means within the column followed by the same letters are not significantly different; $\mathrm{CD}$ : critical difference.

Table 5 Physical characteristics of dates from seedling date palm cultivars of Al-Madinah Al Munawarah region in Saudi Arabia.

\begin{tabular}{llll}
\hline Cultivar code & Fruit length $(\mathrm{mm})$ & Fruit width $(\mathrm{mm})$ & Fruit weight $(\mathrm{g})$ \\
\hline MM-1 & $36.8^{\mathrm{d}}$ & $23.3^{\mathrm{a}}$ & $11.1^{\mathrm{b}}$ \\
MM-2 & $40.3^{\mathrm{b}}$ & $20.2^{\mathrm{b}}$ & $7.5^{\mathrm{d}}$ \\
MM-3 & $37.7^{\mathrm{c}}$ & $17.1^{\mathrm{c}}$ & $7.0^{\mathrm{e}}$ \\
MM-4 & $45.5^{\mathrm{a}}$ & $23.5^{\mathrm{a}}$ & $12.8^{\mathrm{a}}$ \\
MM-5 & $40.5^{\mathrm{b}}$ & $19.6^{\mathrm{b}}$ & $10.8^{\mathrm{b}}$ \\
MM-6 & $31.1^{\mathrm{e}}$ & $23.3^{\mathrm{a}}$ & $10.5^{\mathrm{c}}$ \\
\hline CD $(P=0.05)$ & 0.53 & 0.72 & 0.31 \\
\hline
\end{tabular}

\footnotetext{
${ }^{\mathrm{a}-\mathrm{e}}$ Means within the column followed by the same letters are not significantly different; CD: critical difference.
} 
Table 6 Physical characteristics of dates from seedling date palm cultivars of Al-Qassim region in Saudi Arabia.

\begin{tabular}{lllll}
\hline Sr. No. & Cultivar & Fruit length $(\mathrm{mm})$ & Fruit width $(\mathrm{mm})$ & Fruit weight $(\mathrm{g})$ \\
\hline 1 & Hamdan-1 & $40.3^{\mathrm{m}}$ & $24.1^{\mathrm{h}}$ & $23.1^{\mathrm{a}}$ \\
2 & Bedah-1 & $42.6^{\mathrm{gk}}$ & $30.3^{\mathrm{a}}$ & $14.3^{\mathrm{f}}$ \\
3 & Zamlial-1 & $41.3^{\mathrm{kl}}$ & $25.2^{\mathrm{ef}}$ & $14.7^{\mathrm{e}}$ \\
4 & Hajresiah & $42.9^{\mathrm{fg}}$ & $22.5^{\mathrm{j}}$ & $13.4^{\mathrm{g}}$ \\
5 & Mutair-1 & $28.5^{\mathrm{s}}$ & $16.2^{1}$ & $5.3^{\mathrm{m}}$ \\
6 & Mutair-2 & $45.6^{\mathrm{c}}$ & $20.5^{\mathrm{k}}$ & $8.4^{1}$ \\
7 & Mutair-3 & $44.6^{\mathrm{de}}$ & $29.8^{\mathrm{a}}$ & $15.3^{\mathrm{d}}$ \\
8 & 6421 & $44.5^{\mathrm{e}}$ & $28.3^{\mathrm{b}}$ & $15.3^{\mathrm{d}}$ \\
9 & 6512 & $41.5^{\mathrm{jk}}$ & $20.2^{\mathrm{k}}$ & $14.8^{\mathrm{e}}$ \\
10 & 787 & $39.8^{\mathrm{n}}$ & $23.2^{\mathrm{i}}$ & $11.6^{\mathrm{jk}}$ \\
11 & 196 & $40.7^{\mathrm{m}}$ & $23.4^{\mathrm{i}}$ & $11.9^{\mathrm{ij}}$ \\
12 & 380 & $45.1^{\mathrm{cd}}$ & $24.7^{\mathrm{fg}}$ & $19.2^{\mathrm{b}}$ \\
13 & 4067 & $37.2^{\mathrm{gr}}$ & $22.4^{\mathrm{j}}$ & $8.7^{1}$ \\
14 & 497 & $25.4^{\mathrm{e}}$ & $11.9^{\mathrm{ij}}$ \\
15 & 4013 & $37.5^{\mathrm{op}}$ & $30.4^{\mathrm{a}}$ & $19.2^{\mathrm{d}}$ \\
16 & 632 & $43.3^{\mathrm{f}}$ & $27.3^{\mathrm{c}}$ & $8.7^{\mathrm{g}}$ \\
17 & 3936 & $42.0^{\mathrm{ij}}$ & $24.2^{\mathrm{gh}}$ & $15.2^{\mathrm{hi}}$ \\
18 & 555 & $42.3^{\mathrm{hi}}$ & $24.2^{\mathrm{gh}}$ & $13.4^{\mathrm{h}}$ \\
19 & 6427 & $45.6^{\mathrm{c}}$ & $26.0^{\mathrm{d}}$ & $12.2^{\mathrm{g}}$ \\
20 & 3793 & $47.6^{\mathrm{a}}$ & $27.1^{\mathrm{c}}$ & $13.5^{\mathrm{hi}}$ \\
21 & 365 & $43.3^{\mathrm{f}}$ & $26.1^{\mathrm{d}}$ & $12.3^{\mathrm{c}}$ \\
\hline $\mathrm{CD}(P=0.05)$ & 3803 & $46.5^{\mathrm{b}}$ & $26.4^{\mathrm{d}}$ & $17.1^{\mathrm{k}}$ \\
\hline & & $37.3^{\mathrm{pq}}$ & 0.61 & 0.36 \\
\hline
\end{tabular}

${ }^{\mathrm{a}-\mathrm{s}}$ Means within the column followed by the same letters are not significantly different; $\mathrm{CD}$ : critical difference.

Cumulative analysis (Fig. 2) for the physical fruit characteristics in the different regions indicate that the best mean fruit length was recorded by the seedlings date palm cultivars from Najran $(45.4 \mathrm{~mm})$, while the maximum mean fruit width $(24.9 \mathrm{~mm})$ and weight $(15.4 \mathrm{~g})$ was registered by the cultivars from Al-Qassim and Al-Zulfi, respectively.

\section{Discussion}

Seedlings of date palms are reported to be cultivated for two major reasons: (1) breeding and germplasm conservation and (2) conserve seedling dates with desirable traits for farming [11]. Seedlings of date palm are the original source of most of the present well established cultivars in several countries. Some of the elite palms identified in this study from the five regions of Saudi Arabia could be promoted as new cultivars in the future, but others could serve as a valuable genetic reserve for future crop improvement projects. Fruits of three of the 12 varieties selected from Al-Zulfi had the colour of Sheshi [12] and Sugai, which are well known date palm varieties of the Kingdom. Offshoots of the 12 cultivars selected from the seedling progeny in Al-Zulfi were planted in the gene bank of the Date Palm Research Centre, Al-Hassa, during November, 2012, for further studies and sharing this material with other institutions in the Kingdom and abroad. Among the nine elite seedling progeny palms selected from Al-Hassa, cultivar H-2 registered fruit length $40.7 \mathrm{~mm}$, which was better than large sized fruits of the popular variety Khalas whose mean length was previously reported [12] to be 39.6 $\mathrm{mm}$. Further, with regard to fruit width $(23.6 \mathrm{~mm})$ and weight (15.2 g) of the Al-Hassa cultivars evaluated, maximum values were recorded in cultivar $\mathrm{H}-1$ which was comparable to the medium sized fruits of the popular cultivar Reziz in Al-Hassa region [12].

Larger fruit size has been the most desirable trait in 
case of date palm [2]. In the Western region of Saudi Arabia, large fruit size characteristic of the cultivar Anbarah from Al-Madinah is reported to be a unique variant found with relatively low frequency and a high polymorphic index [13]. The regional mean measurements for fruit size and weight recorded by cultivars in this study, are better than those registered by several well-known cultivars in the Kingdom [12] and meet international standards recommended by Codex Alimentarius Commission, the European Union, United States Department of Food and Agriculture (USDA) and other national standards set by the date exporting countries of North Africa. Identifying, documenting and conserving elite date palm seedling progeny in the Kingdom will go a long way to preserve the valuable genetic resource and also in the commercialization of elite seedling date palm progeny of Saudi Arabia.

\section{Conclusions}

The Kingdom of Saudi Arabia has a wide diversity of date palm cultivars. Several seedling date palm progenies in the Kingdom have been identified by progressive date palm farmers and propagated commercially. This study was taken up with an objective to identify, evaluate and conserve this valuable genetic resource. Twelve potential seedling date palms from the Al-Zulfi and Riyadh regions of the Kingdom were found to produce dates that meet standards for commercial date farming and were much sought after by the farmers of these regions. The cultivars selected can serve as a genetic resource for future crop improvement programs in date palm in the Kingdom and elsewhere and have been conserved in the gene bank of the Date Palm Research Centre, Al-Hassa, Saudi Arabia.

\section{Acknowledgments}

The author gratefully acknowledges the support provided by the Date Palm Research Center, Al-Hassa, Saudi Arabia to carry out this work through the Arab Centre for the Studies of Arid Zones and Dry Lands (ACSAD) Project.

\section{References}

[1] Johnson, D. V. 2010. "Worldwide Dispersal of the Date Palm from Its Homeland.” Acta Hort. 882: 369-75.

[2] Johnson, D. V., Al-Khayri, J. M., and Jain, S. M. 2013. "Seedling Date Palms (Phoenix dactylifera L.) as Genetic Resources.” Emir. J. Food Agric. 25 (11): 809-30.

[3] El-Hadrami, A., and Al-Khayri, J. M. 2012. "Socioeconomic and Traditional Importance of Date Palm.” Emir. J. Food Agric. 24 (5): 371-85.

[4] Food and Agriculture Organization of the United Nations. 2013. "Statistics Division (Crop Production)." Accessed on February 14, 2013. www.faostat.fao.org.

[5] Vayalill, P. K. 2002. "Antioxidant and Antimutagenic Properties of Aqueous Extract of Date Fruit (Phoenix dactylifera L., Arecaceae)." J. Agri. Food Chem. 50 (3): 610-7.

[6] Al-Farsi, M., Alasalvar, C., Morris, A., Barron, M., and Shahidi, F. 2005. "Compositional and Sensory Characteristics of Three Native Sun-Dried Date (Phoenix dactylifera L.) Varieties Grown in Oman.” J. Agri. and Food Chem. 53 (19): 7586-91.

[7] Baloch, M. K., Saleem, S. A., Ahmad, K., Baloch, A. K., and Baloch, W. A. 2006. "Impact of Controlled Atmosphere on the Stability of Dhakki Dates." LWT-Food Sci. and Tech. 39 (6): 671-6.

[8] Zaid, A., and Wet, P. F. 2002. "Origin, Geographical Distribution and Nutritional Values of Date Palm in 2002." In Date Palm Cultivation, edited by Zaid, A. Rome: FAO of the UN.

[9] Ministry of Agriculture, Kingdom of Saudi Arabia. 2006. The Famous Date Varieties in the Kingdom of Saudi Arabia. Saudi Arabia: Ministry of Agriculture, Kingdom of Saudi Arabia and Food and Agriculture Organization of the United Nations, 245.

[10] Association of Official Analytical Chemists (AOAC). 1990. Official Methods of Analysis, 16th ed., Vol. 2. Arlington, Virginia, USA: AOAC Press, 1298.

[11] Johnson, D. V., Rivera, D., Alcaraz, F., Carreño, E., Delgadillo, J., Carrillo, M. H., Obón, C., Krueger, R., and Ríos, S. 2013. "Date Palm (Phoenix dactylifera) Dispersal to the Americas: Historical Evidence of Spanish Introduction." In Proceeding of First International Symposium on Date Palm, 994.

[12] Al-Abdoulhadi, I. A., Al-Ali, S., Khurshid, K., Al-Shryda, F., Al-Jabr, A. M., and Ben-Abdallah, A. 2011. “Assessing Fruit Characteristics to Standardize Quality Norms in Date Cultivars of Saudi Arabia." Indian J. Sci. Technol. 4 (10): 1262-6.

[13] Jaradat, A. A., and Zaid, A. 2004. "Quality Traits of Date Palm Fruits in a Centre of Origin and Centre of Diversity." Food Agric. Environ. 2 (1): 208-17. 